\title{
Contrasting Internationalization Paths of Product- and Service-oriented Software Firms
}

\author{
Arto Ojala \\ University of Jyväskylä \\ arto.k.ojala@jyu.fi
}

\author{
Mikko Rönkkö \\ University of Jyväskylä \\ mikko.ronkko@jyu.fi
}

\author{
Juhana Peltonen \\ Hanken School of Economics \\ juhana.peltonen@hanken.fi
}

\begin{abstract}
The internationalization of software firms has been widely researched topic over the last two decades. However, the most of the studies have treated software firms as a homogeneous group, ignoring the fact that software firms actually differ greatly in terms of having either a product or a service orientation. Based on earlier literature, we hypothesized that software product firms would show a tendency to internationalize earlier and at a smaller size than software service firms, and that product firms would show a greater tendency to target countries that are both geographically and culturally distant. In fact, we found no support for most of our hypotheses, with relatively strong and statistically significant results emerging in the opposite direction. We offer several explanations for these counterintuitive findings.
\end{abstract}

\section{Introduction}

The internationalization of software firms has been widely researched topic over the last two decades in both international business (IB) $[1,2,3,4]$ and information systems (IS) [5, 6, 43] literature. However, most of these studies have treated software firms as a homogenous group, ignoring the fact that software firms can actually differ greatly in terms of their market orientation. Some software firms are pure product firms, developing packaged software products for both $\mathrm{B} 2 \mathrm{C}$ and $\mathrm{B} 2 \mathrm{~B}$ markets, while some software firms are service firms, offering customized services mainly for B2B markets $[7,8,9,10]$. Thus, despite substantial interest in the internationalization of software firms, little is known about how the strategy of the firms concerned - in terms of focusing on either a product or on services - impacts on their internationalization.

In the literature on IB, software firms have been commonly categorized under the service sector, since they produce immaterial products, and closely allied services [11]. However, several works in the field of
IS $[7,9,12,42]$ have indicated that software product firms and software service firms differ in several respects. For instance, the degree of productization appears to be inversely related to the amount of services needed. A low level of productization increases the need for services, since the market offering is then likely to require a high degree of consulting, support, and maintenance [7]. Nambisan [9] argues that software service firms have projectdriven relationships with their customers, whereas software product firms prefer long-term relationships. In addition, he argues that for software service firms, knowledge of the special characteristics of customers is more important than knowledge abstraction. By contrast, software product firms have to be able to capture generic product knowledge, so that the product can be developed for various customer segments [9]. Alajoutsijärvi et al. [12] concluded that service-oriented software firms tend to operate in familiar domestic markets, whereas software product firms target distant, international markets.

The aim of the present study is two-fold. First of all, we aim to contribute to the growing body of literature on the internationalization of software firms by examining the extent to which a product orientation as opposed to a service orientation (involving customization) impacts on the internationalization of software firms. Secondly, this study opens up a unique opportunity to contribute the field of IS by combining IS literature with IB theories. Hence, the second aim is to study how IB theories can explain the internationalization of software product firms and software service firms.

\section{Theoretical considerations and hypotheses}

In this section, we shall first consider the two internationalization theories used in the field of IB and the assumptions of these theories in terms of how they might explain the internationalization of software product and software service firms. 
Thereafter, we shall develop a number of hypotheses for empirical testing. The hypotheses are based on IB theories, IS literature, and the literature on software firms' internationalization, with reference to the product strategies of software firms.

\subsection{The Uppsala Model of Internationalization and INV theory}

The Uppsala model, developed by Johanson and Wiedersheim-Paul [13] and by Johanson and Vahlne [14], describes internationalization as an incrementally evolving process. According to this model, a firm's internationalization is based on increasing market knowledge - knowledge that increases market commitment through commitment decisions and current activities [14]. In their market selection, firms can be expected to enter first into nearby markets that share a similar language, culture, political system, level of education, level of industrial development, and so on. Thereafter, when a firm's knowledge of international operations increases, it will gradually start to develop activities in more distant countries. Thus, knowledge of and learning about foreign markets has a central role. The model further divides knowledge into general knowledge and market-specific knowledge. General knowledge is objective, and transferable from countries previously entered to a target country. It includes general issues related to marketing methods, operation modes, and typical customers on a global scale. Market-specific knowledge is based on previous experiences of the target country environment, including its culture, its market structure, the customers in the market, and so on. This knowledge is mainly acquired through operating in the target country [14]. In their later studies, Johanson and Vahlne $[15,16]$ develop their model so that it comes closer to the network view of internationalization. The studies made along these lines propose that interactions in networks increase firms' knowledge and create new opportunities in international markets.

Whereas the Uppsala model was developed to explain the entire internationalization process of firms, International New Venture (INV) theory focuses on the initiation of internationalization and explains why some firms might be international from their inception [17]. INV theory is motivated by the observation that the internationalization of INVs is related to opportunity-seeking behavior, whereby an entrepreneur "seeks to derive significant competitive advantage from the use of resources and the sale of outputs in multiple countries" [17: p. 49]. It proposes that an INV's origins are international because it has commitments to valuable resources in more than one country. According to the theory, "international from inception" means that the founders of an INV seek growth opportunities in foreign markets having already made some decisions related to the international scope of the activities, even before the founding of the INV [1, 17, 18]. The theory emphasizes that INVs do not have to own their resources, since they are able to use external resources in international markets. Thus, it is the usage of alternative resources for internationalization that distinguishes new ventures from multinational enterprises (MNEs).

In INV theory as proposed by Oviatt \& McDougall [17] the resources that could be utilized were seen to include network structures, since cooperation within a network can create new opportunities for INVs. The importance of networks for INVs is discussed further in the work of Oviatt and McDougall [19]. Because these network relationships cross national borders, it is suggested that the founding teams of INVs must already have knowledge of international markets. The main difference between the Uppsala model [13, 14] and INV theory is that INV theory suggests that firms can skip stages, or not have any intermediate stages at all [17].

\subsection{Software Customization and the Impact of Cultural Distance on Internationalization}

Cultural distance involves a disturbance in information flows between organizations and foreign markets caused by psychological and cultural issues, whether these issues are actual, potential, or perceived [13, 20, 21]. It is connected with the differences in values and behavioral norms between groups of people. Research has been conducted on how differences between groups in various countries adversely affect foreign entry and trade [22]. Thus, there have been studies involving differences in values $[20,21]$ and differences in communication practices [23, 43]. There is broad agreement that cultural distance creates difficulties in communication that may lead to misunderstandings in negotiations with customers in another country.

Product standardization across countries can be expected to compress cultural distance by establishing a common understanding of a product. According to Hoch et al. [17], by manufacturing standardized products that may suit many buyers in varied locations, firms may quickly enter a relatively large number of countries. Thus, there will be less need for deliberate action to overcome cultural distance when one is seeking to sell software 
products in an otherwise distant foreign market. Sometimes product standardization eases the way to the extent that entry into multiple foreign markets can be planned at a venture's inception [17]. In contrast, customized products and services increase the need for face-to-face negotiations, with the possibility that cultural distance will strongly inhibit internationalization. High cultural distance between software entrepreneurs and customers increases the complexity of the information flow [4, 11, 24, 42] and may lead to misunderstandings in communication with customers [24, 25]. Thus, Cornish [26] found that face-to-face meetings were the most important inhibitor for the market expansion of developers of customized software, whereas such meetings played a less important role for developers of standardized software products. These considerations lead us to the following hypothesis:

Hypothesis 1: In comparison with software firms that rely on product sales, firms that rely more on service sales will tend to internationalize to culturally more proximate markets.

\subsection{Software Customization and the Impact of Geographical Distance on Internationalization}

Geographical distance is the physical separation between one location and another, typically involving the space between the home of a firm and the foreign location of the customer [20]. Increasing the physical space between a firm and its customer increase the time and costs related to business transactions [27]. Geographical distance is commonly measured in the kilometers or miles separating two countries or cities. For example, international entrepreneurship scholars have used the air distance between capital cities [28], the miles between the closest seaports in two countries [29], and the kilometers between the geographical centers of countries [4]. Geographical proximity to customers brings with it the benefits of lower economic and managerial costs, rapid and effective information exchange, and environmental familiarity. Recent improvements in transport systems and communication technologies, such as the Internet, have not eliminated the influence of geographical distance on trade intensity between countries [30]. Geographical distance even impacts on the trade in digital goods sold over the Internet [31] and on the market selection of small software firms that trade completely intangible products [4].

In the software industry, software can be delivered electronically around the world using the Internet. This makes geographical distance less important in the delivery process. Nevertheless, the sales process may require considerable liaison with customers to specify requirements, install the software, and provide after-sales support [see e.g. [32]. O'Farrell et al. [11] found that in the software industry there remains a need for frequent face-toface negotiations with customers. Along similar lines, Bell [24] found that frequent customer visits were required for software providers, because software frequently requires installation, customization, training, maintenance, and back-up services. Because software service providers collaborate with customers more frequently $[9,11,12,33]$, one can expect geographical distance to be a correspondingly powerful inhibitor for their internationalization. This leads us to the following hypothesis:

Hypothesis 2: Compared to software firms that rely on product sales, software firms that rely more on service sales will tend to internationalize to geographically more proximate markets.

\subsection{Software Customization and the Speed of Internationalization}

Under the Uppsala model, the basic assumption is that a firm will operate first in the domestic market before internationalizing its operations to foreign countries [13, 14]. During the domestic period, it can acquire knowledge and financial resources for foreign operations. In contrast, INV theory suggests that entrepreneurs are able to use existing resources and network relationships to internationalize in foreign markets - to the extent that in some cases they may even ignore the home market [17]. In their integrative model of internationalization, Bell, McNaughton, Young and Crick [35] propose that service-intensive firms may spend a longer domestic period before internationalization compared to knowledge-based firms. This idea is based on the fact that service-oriented firms are likely to have to spend time on designing, testing, and developing services for foreign markets. Knight [36], too, argues that service firms need time to acquire foreign market knowledge if they are to develop their service offering for international markets. In the software industry, software service firms have seen as aiming to be more local than software product firms, due to the need for software service firms to be aware of their customers' specific requirements and to locate near to them [see e.g. 12, 33, 34]. Thus, according to the considerations above, one can expect software service firms to internationalize their operations to foreign markets later than software product firms. This leads to the following hypothesis: 
Hypothesis 3: Software firms that rely more on service sales will tend to internationalize later than software firms that rely on product sales.

\subsection{Software Customization, Firm Size and Internationalization}

Based on the hypotheses above, it can also be expected that software service firms will internationalize at a larger size than software product firms, because they will need more resources to develop their services for foreign customers [34]. During the domestic period, software service firms must acquire resources to develop their services for foreign customers, and to overcome the costs of doing business with foreign customers. Ellis [29] theorizes that when the distance between a buyer and a seller increases, the costs of doing business will become higher, offsetting the benefits of operating in a distant market. Like other types of distance, geographical distance has inhibiting effects, increasing the costs of travel. Software product firms can avoid these problems by developing standardized products. Such products are easy to deliver in electronic mode, and they are made to suit the needs of many buyers in varied locations. By contrast, software service firms are dependent on face-to-face contacts with customers, and these will increase the cost of doing business. Cornish [37, p. 1679] takes the view that "the greater the customization of a service, the more important face-to-face contact is likely to be, the steeper the spatial cost curve, and the more differentiated such services will have to be to be exportable". Software services are also difficult to maintain, and when a software service firm grows, it has to continuously develop its services in order to meet the customers' requirements [34]. This leads us to the following hypothesis:

Hypothesis 4: Software firms that rely more on service sales will tend to internationalize at a larger size than software firms that rely on product sales.

\section{METHODS}

\subsection{Sample and Data Collection}

The present paper uses empirical data collected from the Finnish software industry by the annual National Software Industry Survey over the years 2000-2011 [38]. Because the data come from twelve different surveys, and because the sampling frame of these studies has evolved over the years, we shall provide only an overview of the sample. Detailed descriptions of the sample and of the data collection procedures for each year are available in the National Software Industry Survey reports [38]. The most significant change in the sampling frame took place in 2008, when the survey was expanded from covering merely software product firms to the entire software industry, with the inclusion also of service firms. Prior to this year, some software service firms had been included (because they were listed in some of the data sources used to construct the sampling frame), but they were not covered systematically.

Although the details of the sampling frame have evolved over the years, a majority of the responding firms are currently registered under NACE codes 7221 ("Publication of software") and 7222 ("Other software consultancy and supply"). To cover the entire software industry, including also firms officially registered under other industry codes, the membership lists of several industry organizations were consulted. This approach was adopted because some firms have software as a secondary industry and would thus not be included in a sampling frame constructed purely from the primary industry codes. Typically, the sampling frame in this study covered all firms with five or more people. We used data from the Finnish trade register to include smaller enterprises only if the enterprises in question were members of some industry association or had registered on any of the lists covering the software industry. However, the coverage of the smallest firms varies from year to year.

Data collection in the National Software Industry Surveys [38] uses paper and web-based questionnaires loosely following the tailored design approach [39]. The process involves sending paper invitations that are addressed the CEOs of the firms. However, to increase the response rate, email reminders are also sent to a maximum of two other firm representatives of the firm's top management. Since one of the goals of the National Software Industry Survey is to cover the entire industry, this figure represents a significant amount of oversampling, which aims to assure that relevant firms answer as often as possible. As a result, the average response rate of approximately $10 \%$ may be somewhat reduced. Furthermore, the accuracy of prescreening the address list and removing firms that are either inactive of not software firms seems to explain variation on response rates: From 2008 to 2011 the number of responses has varied quite modestly between 506 and 650, while the total number of invitations sent has varied more significantly between 3962 and 7578 . Prior to 2008, both the number of 
responses and invitations sent were approximately one half compared to later surveys.

The survey forms for the 2008 and 2011 surveys included a question about the first three target markets and about the years of entry. These data were used to compile a list of first internationalization events (year and country) for all the firms that provide a response. We then combined this list with the survey responses for the earlier years to obtain a dataset that described the first international entries (year and country) and the survey data about each firm for the year that the first international entry took place. For example, if a firm responded to 2008 survey that their first international entry took place in 2006, we combined the data about the international entry with the survey data from 2006 for this firm. This longitudinal design limited our sample size to 147 separate firms. In order to better isolate the effect of product sales, we decided to limit the sample to software product and software service firms, omitting all firms which identified themselves as being primarily hardware, consulting, or reseller firms (responding to a question in which the firm was asked which of these five business models best described their main business). By focusing only on these two categories, product and service, we are left with firms that differ mainly by how they use the outputs of their software development capability to form a market offering. This led to a data set of 118 firms. Table 1 lists the years of internationalization (entry to the foreign market) and the surveys (2008 and 2011) from which the data on internationalization were obtained.

Table 1: Years of entry to the foreign market, by response year

\begin{tabular}{lrrr}
\hline & \multicolumn{3}{c}{ Response year } \\
\cline { 2 - 4 } Entry year & 2008 & 2011 & Total \\
\hline 2000 & 3 & 4 & 7 \\
2001 & 4 & 2 & 6 \\
2002 & 3 & 1 & 4 \\
2003 & 2 & 6 & 8 \\
2004 & 6 & 7 & 13 \\
2005 & 3 & 4 & 7 \\
2006 & 9 & 5 & 14 \\
2007 & 6 & 8 & 14 \\
2008 & 1 & 8 & 9 \\
2009 & 0 & 11 & 11 \\
2010 & 0 & 22 & 22 \\
2011 & 0 & 3 & 3 \\
Total & 37 & 81 & 118 \\
\hline
\end{tabular}

\subsection{Measures}

3.2.1. Dependent variables. The cultural distance of the international entry country was calculated using Hofstede's [21] cultural dimensions, applied to the first target country and Finland. For the geographical distance (of the international entry country), we obtained the centric coordinates of the country from the CIA World Factbook and compared these with the coordinates of Finland. With both variables, the effect of one additional unit of distance can be expected to diminish as the overall distance gets greater and therefore we modeled relative effects by applying log transformation to both variables. There were 26 firms that provided data for the first target market in 2008 and then again in 2011, enabling us to assess test-retest reliability of this variable. Cramér's $\mathrm{V}$ between the two measurements was .91 , indicating that while there was some recall bias, the variable was generally very reliable.

Firm age and firm revenue for the year of internationalization were obtained from Bureau Van Dijk's Orbis database. The Orbis database obtains data from the publicly accessible Finnish Trade Register, to which by law all firms registered in Finland must report their annual financial information. To reflect the fact that absolute changes in age and revenue are less substantial for larger and older firms, we applied log transformation to study the relative effects of these variables.

3.2.2. Independent variables. We measured the product vs. service focus via a variable called IPR intensity. This was operationalized by asking the informants to describe how their revenues were distributed among the following sources: (i) 3rd party software licenses, (ii) ASP and SaaS, (iii) content and advertisement, (iv) deployment projects, (v) development projects, (vi) hardware, (vii) maintenance, (viii) not software related, (ix) other software related, and (x) own software licenses. We created the IPR intensity variable as a sum of the items that were closely related to product sales ( $3 \mathrm{rd}$ party software licenses, ASP and SaaS, and own software licenses). The data for this variable were obtained from surveys for the different years (2000 to 2011) matching the internationalization events.

Revenue distributions may nevertheless be inadequate in describing the nature of a young growth-minded firm, which is only just setting up operations. Hence, we triangulated the revenue sources data via a question that asked the firm to choose which of the following five categories best described their business: (i) software product firm, (ii) firm that manufactures devices that contain 
software (embedded software), (iii) firm that delivers software projects or other related services, (iv) consulting firm in the software industry or closely related to it, or (v) software reseller. After removing the consulting, hardware, and reseller firms, we created the software product firm dummy variable, which receives the value of 1 when the firm reports itself to be a software product firm, and 0 when it reports itself as a software service firm.

\subsection{Analysis}

Data analysis was carried out using Stata, version 10.1. After data preparation (calculating the values for the study variables on the basis of the survey responses) the data were analyzed using an OLS regression analysis with heteroskedasticity robust standard errors for models with size, age, and cultural distance as the dependent variable. The regression models of geographical distance had a residual distribution that was distinctly non-normal. This is quite natural, considering that the firms mainly export to Europe (near), South-East Asia (far), and the Americas (far). Due to this violation of OLS assumptions, we instead used median regression. With this alternative regression estimator, the residual distribution was much less problematic, and there were no correlations or heteroskedasticity of residuals.

\section{RESULTS}

Table 2 presents the descriptive statistics for our data set. The table demonstrates that countries that are geographically more distant are also culturally more distant, and also that firms that internationalize later are larger when they do so.

Table 2: Descriptive statistics and correlations

\begin{tabular}{lrrrcccc}
\hline & Mean & SD & 1 & 2 & 3 & 4 & 5 \\
\hline $\begin{array}{l}\text { Cultural } \\
\text { distance (In) }\end{array}$ & 0.66 & 0.37 & & & & & \\
$\begin{array}{l}\text { Geographic } \\
\text { distance }\end{array}$ & & & & & & & \\
(kilometers, ln) & 7.85 & 0.95 & $0.70^{* * *}$ & & & & \\
IPR intensity & 0.20 & 0.31 & $-0.10^{*}$ & -0.07 & & & \\
Software product & & & & & & & \\
firm & .556 & .497 & $-.174^{* * *}$ & $-.133^{* *}$ & $.34^{* * *}$ & & \\
Revenue (In) & 13.54 & 1.49 & 0.07 & -0.02 & $-0.19^{* * *}$ & $-0.10^{*}$ & \\
Age (ln) & 1.94 & 0.83 & 0.03 & -0.06 & 0.04 & $0.11^{*}$ & $0.28^{* * *}$ \\
\hline${ }^{*} p<0.05,{ }^{* *} p<0.01,{ }^{* * *} p<0.001$ & & & & &
\end{tabular}

The regression analyses summarized in Table 3 and Table 4 show counterintuitive results. Not only are hypotheses 1-3 not supported, but there seem to be relatively strong and statistically significant results in the opposite direction. In other words, product firms tend to internationalize later than services firms, and tend to target countries that are both geographically and culturally closer than those targeted by service firms. However, when controlled for firm age, our analyses suggest that software product firms are indeed smaller than software service firms when they internationalize, thus giving support to hypothesis 4.

Table 3: Determinants of distance of first international entry country

\begin{tabular}{|c|c|c|c|c|c|c|}
\hline & \multicolumn{3}{|c|}{ Cultural distance (ln) } & \multicolumn{3}{|c|}{$\begin{array}{l}\text { Geographic distance (kilometers, } \\
\qquad \ln )\end{array}$} \\
\hline & (1) & $(2)$ & (3) & (4) & (5) & (6) \\
\hline IPR intensity & $-0.156^{\dagger}$ & & -0.073 & -0.393 & & -0.079 \\
\hline Revenue (1n) & -0.009 & -0.010 & -0.013 & -0.102 & $-0,050$ & -0.033 \\
\hline Age (ln) & 0.043 & 0.065 & 0.066 & $-0.366^{* *}$ & -0.099 & -0.111 \\
\hline Software service firm & & ref. & ref. & & ref. & ref. \\
\hline Software product firm & & $-0.206^{* *}$ & $-0.194^{* *}$ & & $=0.609^{* * *}$ & $-0.588^{* * *}$ \\
\hline Intercept & $0.762^{*}$ & $0.825^{* *}$ & $0.867^{* *}$ & $9.746^{* * *}$ & $8.710^{* * * *}$ & $8.516^{* * *}$ \\
\hline Observations & 118 & 118 & 118 & 118 & 118 & 118 \\
\hline $\mathrm{R}^{2}$ & 0.024 & 0.081 & 0.084 & & & \\
\hline Adjusted $R^{2}$ & -0.002 & 0.056 & 0.052 & & & \\
\hline $\mathrm{F}$ & 1.173 & 3.126 & 2.607 & & & \\
\hline $\mathrm{p}$ & 0.323 & 0.029 & 0.039 & & & \\
\hline Pseudo- $\mathrm{R}^{2}$ & & & & 0.029 & 0.059 & 0.059 \\
\hline \multicolumn{7}{|c|}{${ }^{\dagger} p<0.1,{ }^{*} p<0.05,{ }^{* *} p<0.01,{ }^{* * *} p<0.001$} \\
\hline \multicolumn{7}{|c|}{ Linear regression (Models 1, 2,3) } \\
\hline Median regression (Models & $4,5,6)$ & & & & & \\
\hline
\end{tabular}

Table 4: Determinants of age and size during first international entry

\begin{tabular}{|c|c|c|c|c|c|c|}
\hline & \multicolumn{3}{|c|}{ Age (ln) } & \multicolumn{3}{|c|}{ Revenue (ln) } \\
\hline & (1) & (2) & (3) & (4) & (5) & (6) \\
\hline IPR intensity & 0.234 & & 0.087 & $-0.837^{*}$ & & $-0.765^{\dagger}$ \\
\hline Revenue (ln) & $0.195^{* * *}$ & $0.191^{* * *}$ & $0.195^{* * *}$ & & & \\
\hline Software service firm & & ref. & ref. & & ref. & ref. \\
\hline Software product firm & & $0.335^{*}$ & $0.320^{*}$ & & -0.302 & -0.161 \\
\hline Age $(\ln )$ & & & & $0.550^{* * *}$ & $0.574^{* * *}$ & $0.567^{* * *}$ \\
\hline Intercept & -0.792 & -0.886 & -0.936 & $12.357^{* * *}$ & $12.331^{* * *}$ & $12.403^{* * *}$ \\
\hline Observations & 118 & 118 & 118 & 118 & 118 & 118 \\
\hline $\mathrm{R}^{2}$ & 0.108 & 0.141 & 0.142 & 0.135 & 0.112 & 0.138 \\
\hline Adjusted $\mathrm{R}^{2}$ & 0.093 & 0.126 & 0.119 & 0.120 & 0.096 & 0.115 \\
\hline $\mathrm{F}$ & 8.887 & 12.329 & 8.270 & 10.149 & 7.555 & 6.824 \\
\hline $\mathrm{p}$ & 0.000 & 0.000 & 0.000 & 0.000 & 0.001 & 0.000 \\
\hline
\end{tabular}

We tested the robustness of the results in several different ways. As a first test, we performed the analysis using the first three target markets instead of using only data on the first international entry. The results from this analysis were similar to the results for the first international entry. In fact, with the larger amount of observations (408), the statistical significance for the results increases. In particular, the IPR intensity variable shows statistically significant results in all but one of the models. Thus, the results are in line with analyses where the software product firm variable is used as an alternative operationalization. We also considered 
that the close economic and cultural ties between Finland and other Nordic countries (including Estonia) might introduce effects that are not generalizable. However, the analyses remained robust when these international entries were removed from the data set.

\section{DISCUSSION}

From our findings it appears that product firms tend to internationalize later than services firms, and that product firms tend to target countries that are both geographically and culturally close. Although the findings are not in line with previous literature on the internationalization of software firms, nor with the prevalent assumptions in internationalization theories, one can find arguments for these seeminglyanomalous findings. These are set out below.

In the first place, it will be recalled that the existing literature $[4,11,23,25]$ on software firms' internationalization favors the view that increased cultural distance will inhibit software service firms in particular, due to the fact that communication with customers will be difficult. However, in the software industry, firms have their own worldwide norms, standards, and language, despite the differing national backgrounds among industry players [cf. 40]. Thus, software service firms which operate in B2B markets and which develop consultancy solutions for narrow customer segments $[8,9,12]$ can use their industry-specific knowledge - knowledge that is by no means country-specific, and which can be applied to a number of foreign markets. This finding is in line with the study by Sharma and Johanson [41], who investigated firms in the technical consultancy sector. In contrast, software product firms, which develop their software for a wide customer segment, have to take cultural and linguistic issues into the consideration when they develop their software products for foreign countries.

Secondly, because software service firms conduct their operations in a project-based business, they do not have to make commitments to specific foreign markets in the same sense as software product firms must do. This argument is in line with the findings of Kuivalainen [33], indicating that software service firms are more likely to operate through foreign direct investments than is the case with software service firms. This makes geographical distance less important for service firms, given that a firm can conduct a project for a customer in a country, and then exit from that country and start a new project in another country. This finding is also related to general differences between software product and software service firms, if one takes the view that software product firms favor long-term relationships with customers whereas software service firms have short-term, project-driven relationships [9]. Furthermore, in project business, customers are commonly charged for traveling costs, making the geographical location of the project less important. In addition, in many cases, certain elements of the project for a foreign customer can be conducted within a firm's premises in the home country, and that decreases the need for travelling. From the perspective of the Uppsala model, there is no need for the provider to make a commitment to a particular market as the location of customers is less important and may be constantly changing [cf. 14].

Thirdly, in line with findings from the technical consultancy sector [41], it seems that software service firms can use their industry-specific knowledge as an advantage for early internationalization. Because this knowledge is based on the experiences of employees, it can be quickly mobilized and the knowledge can be sold for foreign customers. In contrast to software product firms, software service firms do not need to spend time on product development or on localization in respect of foreign markets. In addition, their knowledge does not need to be market- or country-specific in the manner proposed in the Uppsala model [13, 14]. Software service firms can use their specific technical knowledge and related ability to solve customers' specific problems as their main resource for internationalization. Compared to software product firms, they can "skip" the product development phase, which itself takes time and slows down internationalization. This argument is in line with the view of Oviatt and McDougall [19, p. 543] that "knowledge-type may influence how quickly an entrepreneurial opportunity is exploited."

\section{CONCLUSIONS}

This study contributes both IB and IS literature. It provides evidence that the impact of geographical and cultural distance, as highlighted in the Uppsala model [14], may in fact be more relevant for software product firms than for software service firms. It seems that market-specific knowledge is important for software product firms, whereas software service firms can utilize their technical and industry-specific knowledge when they implement projects for foreign customers. Because this kind of knowledge is quickly mobilized, software service firms can enter foreign markets more rapidly than software products firms, which are dependent on product development and localization in their dealings with foreign clients. In addition, software service firms do not need to make 
commitments to specific markets, as they have shortterm relationships with their customers [9]. By contrast, market commitment may become increasingly important for software product firms, which favor long-term relationships. Thus, the internationalization of software service firms is more related to INV theory $[17,19]$, according to which market commitment is not important, and in which the importance of existing knowledge for early internationalization is highlighted.

Overall, our findings bring new knowledge related to the internationalization of software firms. First of all, the results clearly indicate that there are differences between the internationalization processes of different types of software firm -an aspect that has been largely neglected in earlier studies [2, 3, 4, 24]. Hence, studying software firms as a homogeneous group may well produce confusing results, depending on the distribution of software product and software service firms in the sample. Secondly, it seems that cultural or geographical issues such as communication and collaboration with foreign customers $[4,9,12,26]$ maintenance of services [34], and location close to customers [12, 33, 34] may not inhibit software service firms' internationalization to the extent envisaged in previous literature.

As with all studies, ours has certain weaknesses. In this study we focused only on firms that operate internationally. Although the findings here indicate that software service firms internationalize their operations earlier and to more distant countries than software product firms, many software service firms may operate only locally. Thus, it would be interesting to study the differences between local and internationally oriented software service firms. Secondly, because of the method used here, we do not have the kind of detailed data that might explain the specific reasons behind the different patterns of internationalization observed in software product and software service firms. Thus, in-depth case studies are needed to find factors that would explain how and why the firm-types in question internationalize their operations in a different manner. It would also be beneficial to determine how these firms use their network relationships in the internationalization, and whether there are differences in the formation and utilization of network relationships between software product and software service firms. Thirdly, all the normal caveats about studies on single industries and single countries apply here. In particular, due to small home markets, Finnish software firms probably internationalize at a smaller size than is the case with firms with larger home markets. In addition, we asked about the first international market retrospectively, and this raises the possibility of survivorship bias. Finally, firms which attempted international expansion, but whose efforts resulted in failure and discontinuation of the firm, were not included in the sample. Because of this, the findings may be better generalized to firms that have actually succeeded in their internationalization.

\section{REFERENCES}

[1] Ojala, A, Evers, N., Rialp, A. 2018. Extending the international new venture phenomenon to digital platform providers: A longitudinal case study. Journal of World Business, 53(5): 725-739.

[2] Coviello, N. 2006. The network dynamics of international new ventures. Journal of International Business Studies, 37(5): 713-731.

[3] Lopez, L.E., Kundu, S.K., Ciravegna, L. 2009. Born global or born regional? Evidence from an exploratory study in the Costa Rican software industry. Journal of International Business Studies, 40(7): 1228-1238.

[4] Ojala, A., Tyrväinen, P. 2007. Market entry and priority of small and medium-sized enterprises in the software industry: An empirical analysis of cultural distance, geographical distance, and market size. Journal of International Marketing, 15(3): 123-149.

[5] Su, N. 2013. Internationalization Strategies of Chinese IT Service Suppliers. MIS Quarterly 37(1): 175-200.

[6] Zhang, M., Sarker, S., Sarker, S. 2013. Drivers and export performance impacts of IT capability in 'bornglobal' firms: a cross-national study. Information Systems Journal, 23(5): 419-443.

[7] Hoch, D.J., Roeding, C.R., Purkert, G., Lindner, S.K., Müller, R. 2000. Secrets of Software Success. Boston: Harvard Business School Press.

[8] Ibert, O. 2004. Projects and firms as discordant complements: organisational learning in the Munich software ecology. Research Policy, 33(10): 1529-1546.

[9] Nambisan, S. 2001. Why Service Business Are Not Product Businesses. MIT Sloan Management Review, 42(4): 72-80.

[10] Nambisan, S. 2002. Software Firm Evolution and Innovation-orientation. Journal of Engineering and Technology Management, 19(2): 141-165.

[11] O'Farrell, P.N., Wood, P.A., Zheng, J. 1998. Internationalisation by Business Service SMEs: An InterIndustry Analysis. International Small Business Journal, 16(2): 13-33.

[12] Alajoutsijärvi, K., Mannermaa, K., Tikkanen, H. 2000. Customer Relationships and the small software firm: A framework for understanding challenges faced in marketing. Information \& Management, 37(3): 153-159. 
[13] Johanson, J., Wiedersheim-Paul, F. 1975. The internationalization of the firm: four Swedish cases. Journal of Management Studies, 12(3): 305-322.

[14] Johanson, J., Vahlne, J-E. 1977. The internationalization process of the firm: a model of knowledge development and increasing foreign market commitments. Journal of International Business Studies, 8(1): 23-32.

[15] Johanson, J., Vahlne, J-E. 2003. Business Relationship Learning and Commitment in the Internationalization process. Journal of International Entrepreneurship, 1(1): 83-101.

[16] Johanson, J., Vahlne, J-E. 2009. The Uppsala internationalization process model revisited: From liability of foreignness to liability of outsidership. Journal of International Business Studies, 40(9): 1411-1431.

[17] Oviatt, B.M., McDougall, P.P. 1994. Toward a theory of international new ventures. Journal of International Business Studies, 25(1): 45-64.

[18] McDougall, P.P., Shane, S., Oviatt, B.M. 1994. Explaining the formation of international new ventures: The limits of theories from international business research, Journal of Business Venturing, 9(6): 469-487.

[19] Oviatt, B.M., McDougall, P.P. 2005. Defining international entrepreneurship and modeling the speed of internationalization. Entrepreneurship Theory and Practice, 29(5): 537-553.

[20] Ojala, A. 2015. Geographic, cultural, and psychic distance to foreign markets in the context of small and new ventures. International Business Review, 24(5), 825-835.

[21] Hofstede, G. 2001. Culture's Consequences ( $2^{\text {nd }}$ ed.). Second edition. NY: Sage.

[22] Shenkar, O. 2001. Cultural Distance Revisited: Towards a More Rigorous Conceptualization and Measurement of Cultural Differences. Journal of International Business Studies, 32(3): 519-535.

[23] Hall, E.T., \& Hall, M.R. 1990. Hidden Differences: Doing Business with the Japanese. New York: Anchor.

[24] Bell, J. 1997. A Comparative Study of the Export Problems of Small Computer Software Exporters in Finland, Ireland and Norway. International Business Review, 6(6): 585-604.

[25] Ojala, A., Tyrväinen, P. 2007. Entry barriers of small and medium-sized software firms in the Japanese market. Thunderbird International Business Review, 49 (6): 689705 .

[26] Cornish, S.L. 1997. Product Innovation and the Spatial Dynamics of Market Intelligence: Does Proximity to Markets Matter? Economic Geography, 73(2): 143-165.

[27] Dow, D. 2000. A Note on Psychological Distance and Export Market Selection. Journal of International Marketing, 8(1), 51-64.
[28] Terpstra V., \& Yu, C-M. 1988. Determinants of foreign investment of U.S. advertising agencies. Journal of International Business Studies, 19(1): 33-46.

[29] Ellis, P. 2008. Does psychic distance moderate the market size-entry sequence relationship? Journal of International Business Studies, 39(3): 351-369.

[30] Leamer, E.E., Storper, M. 2001. The Economic Geography of the Internet Age. Journal of International Business Studies, 32(4): 641-665.

[31] Blum, B.S., Goldfarb, A. 2006. Does the Internet defy the law of gravity? Journal of International Economics, 70(2): 384-405.

[32] Ojala, A., Tyrväinen, P. 2006. Business models and market entry mode choice of small software firms. Journal of International Entrepreneurship, 4(2-3): 69-81.

[33] Kuivalainen, O. 2001. Impact of the Product Characteristics on the Internationalisation Processes of the Born Globals - The Case of the Finnish Telecommunication and Information Technology Software Suppliers and Content Providers as an Example. In W.E. During, R. Oakey, \& S. Kauser (Eds.), New Technologybased Firms in the New Millennium: 26-41. Pergamon Press.

[34] Brouthers, K.D., van't Kruis, Y.M. 1997. Competing in Software: Strategies for Europe's Niche Business. Long Range Planning, 30(4): 518-528.

[35] Bell, J., McNaughton, R., Young, S., Crick, D. 2003. Towards an Integrative Model of Small Firm Internationalisation. Journal of International Entrepreneurship, 1(4): 339-362.

[36] Knight, G. 1999. International services marketing: review of research, 1980-1998. Journal of Services Marketing, 13(4/5): 347-360.

[37] Cornish, S.L. 1996. Marketing software products: the importance of 'being there' and the implications for business service exports. Environment and Planning A, 28(9): 1661-1682.

[38] Rönkkö, M., Ylitalo, J., Peltonen, J., Parkkila, K., Valtakoski, A., Koivisto, N., Alanen, L., et al. (2010). Software Industry Survey 2010. Espoo, Finland: Aalto University. Retrieved from http://www.softwareindustrysurvey.org/ReportFinland2010 .pdf

[39] Dillman, D.A. 2007. Mail and Internet surveys: The tailored design method. New York: Wiley.

[40] Andersson, S. 2004. Internationalization in different industrial contexts. Journal of Business Venturing, 19(6): 851-875.

[41] Sharma, D.D., Johanson, J. 1987. Technical consultancy in internationalization. International Marketing Review, 4(4): 20-29

[42] Ojala, A., Paavilainen-Mäntymäki, E., Su, N., Lyytinen, K. 2017. Software Complexity and Organization 
of Firms' Offshoring Activities. Scandinavian Conference on Information Systems, 15-27.

[43] Su, N. 2015. Cultural Sensemaking in Offshore Information Technology Service Suppliers: A Cultural Frame Perspective. MIS Quarterly 39(4): 959-983. 